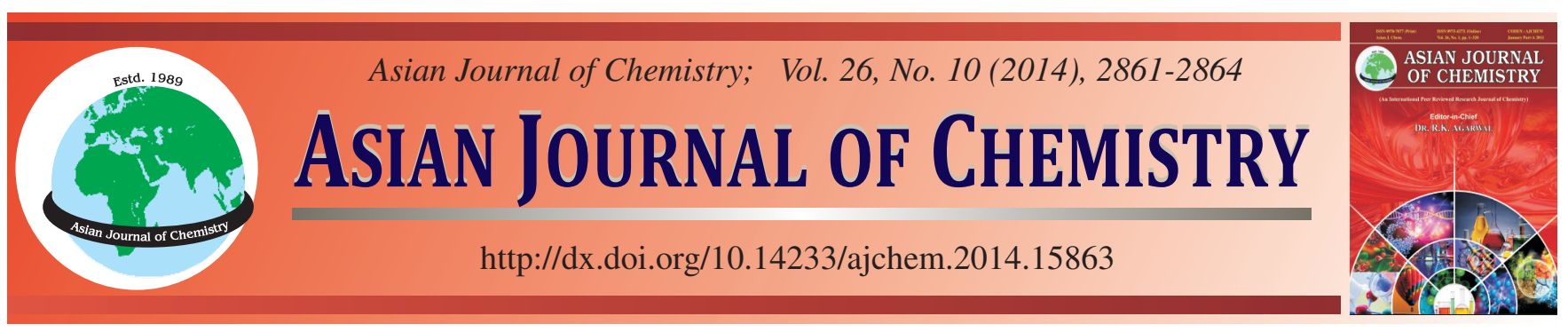

\title{
Production and Characterization of Collagenolytic Protease from Bacillus licheniformis F11.4 Originated from Indonesia
}

\section{Ace Baehaki ${ }^{1}$, Sukarno ${ }^{2}$, Dahrul Syah ${ }^{2}$, Siswa Setyahadi ${ }^{3}$ and Maggy T. Suhartono ${ }^{2, *}$}

\begin{abstract}
${ }^{1}$ Department of Fisheries Product Technology, Faculty of Agriculture, Sriwijaya University, Indralaya, South Sumatera, Indonesia ${ }^{2}$ Department of Food Science and Technology, Faculty of Agricultural Technology, Bogor Agricultural University, Bogor, Indonesia ${ }^{3}$ Agency for the Assessment and Application of Technology, Republic of Indonesia, Jakarta, Indonesia

*Corresponding author: E-mail: mthenawidjaja@yahoo.com
\end{abstract}

Received: 5 June 2013;

Accepted: 13 January 2014;

Published online: 10 May 2014;

AJC-15135

Two mutant derivatives of the potent protease producing Bacillus licheniformis strain F11, originally isolated from Palembang, Sumatera, were checked for their capacity to secrete proteases: B. licheniformis F11.1, with a frame shift mutation in chiA and having deleted the genes for polyglutamate synthesis (genotype $\Delta c h i A ; \Delta p g a$ ) and B. licheniformis F11.4 with a deletion spanning both of the chitinase encoding genes (genotype $\Delta c h i A B ; \Delta p g a$ ). Bacillus licheniformis F11.4 was screened and isolated from Palembang, Indonesia. The bacteria produced collagenase enzyme when grown in a collagen media. The purpose of this study was to characterize the collagenase enzyme. Addition of collagen in the media accelerated the collagenase production time and increase the activity. The optimal temperature and $\mathrm{pH}$ of the enzyme were $50{ }^{\circ} \mathrm{C}$ and $\mathrm{pH} 9$, respectively. At $\mathrm{pH} 12$, the collagenase activity was still high. Collagenase activity was inhibited by $\mathrm{Cu}^{2+}(\mathrm{I} \mathrm{mM})$ and stimulated by $\mathrm{Co}^{2+}(1 \mathrm{mM}), \mathrm{Mg}^{2+}(1 \mathrm{mM})$ and $\mathrm{Ca}^{2+}(1 \mathrm{mM})$. The collagenase from B. licheniformis $\mathrm{F} 11.4$ was capable of hydrolyzing collagen and other protein substrates such as casein, gelatin and fibrin.

Keywords: Collagenase, Characterization, Bacillus licheniformis F11.4.

\section{INTRODUCTION}

Collagenase are metalloprotease enzymes which can cleave helical collagen into small peptide fragments. The enzyme plays a major role in connective tissue metabolism and is produced by specific cells involved in repairs and remodeling processes. Previous studies reported that some bacterial collagenase can degrade collagen in both of the denatured and undenatured form. The most commonly used microbial collagenase in medical products was that of Clostridium histolyticum ${ }^{1}$, Pseudomonas sp. ${ }^{2}$, Bacillus licheniformis $\mathrm{N} 22^{3}$, Bacillus pumilus CoI-J ${ }^{4}$, (Streptomyces parvulu ${ }^{5}$, Streptomyces sp. Strain $3 \mathrm{~B}^{6}$ and Cytophaga sp. L43-17.

In search of the protease producing microorganisms which can be applied in deproteination process for chitin extraction from the shrimp waste, we found isolate Bacillus licheniformis F11. Bacillus licheniformis F11 was screened from a total of 109 isolates originated from Palembang South Sumatera during exploration of chitinase and protease producing indigenous microorganisms. Study on physiological tests and $16 \mathrm{~S}$ rRNA gene comparison, as well as microscopic and macroscopic investigations had been conducted ${ }^{8}$. The amino acid alignments revealed 99 to $100 \%$ identity to the known B. licheniformis loci, with frameshift mutation detected in F11 strain. This is responsible for lack of producing chitinase but actively hyper secreting protease. The protease from $B$. licheniformis F11 is good for deproteinization of shrimp waste in chitin production ${ }^{8}$. Two mutants of $B$. licheniformis F11 were found: $B$. licheniformis F11.1 which lack of gene encoding ChiA and B. licheniformis F11.4 which lack of gene encoding ChiA and $\mathrm{B}^{9}$.

In this research, we reported that B. licheniformis F11.4 originated from Palembang secreted collagen degrading enzymes. Preliminary characterization of the extracellular collagenase was presented.

\section{EXPERIMENTAL}

Effect of collagen on enzyme production: Two types of media were used for bacterial growth and protease production i.e., Luria Broth (LB) and modified Luria Broth plus collagen (MLB + collagen) media. The LB media contained tryptone $1 \%, \mathrm{NaCl} 1 \%$ dan yeast extract $0.5 \%$ (w/v). The modified $\mathrm{LB}+$ collagen media contained tryptone $0.5 \% ; \mathrm{NaCl} 1 \%$, yeast extract $0.25 \%$ and colllagen $5 \%(\mathrm{w} / \mathrm{v})$. The cell growth was monitored turbidimetrically through absorbance at $\lambda=$ $620 \mathrm{~nm}$. As much as $10 \%$ of seedling culture with optical density of 0.8 (at $620 \mathrm{~nm}$ ) was sub-cultured into the same 
media for enzyme production. Incubation was conducted at $37^{\circ} \mathrm{C}$ and samples were taken for analysis of enzyme activity, protein concentration and cell growth.

Assay of collagenase activity and protein determination: Collagenase activity was measured according to the Bergmeyer method ${ }^{10}$ with collagen from fish skin $(5 \%)$ as the substrate. As much as $50 \mu \mathrm{L}$ enzyme filtrate was mixed with $250 \mu \mathrm{L}$ substrate and incubated for $10 \mathrm{~min}$ at $37^{\circ} \mathrm{C}$. $500 \mu \mathrm{L}$ Trichoracetic acid (TCA) $0.2 \mathrm{M}$ was added and incubated at $37^{\circ} \mathrm{C}$ for $10 \mathrm{~min}$, followed by centrifuged at $4000 \mathrm{~g} 10 \mathrm{~min}$. The supernatant was mixed with $1.25 \mu \mathrm{L} \mathrm{Na}_{2} \mathrm{CO}_{3} 0.4 \mathrm{M}$, followed by addition $250 \mu \mathrm{L}$ Folin-Ciocalteau reagent (1:2) and incubation furthur at $37^{\circ} \mathrm{C}$ for $20 \mathrm{~min}$. The reaction products was measured at $\lambda 578 \mathrm{~nm}$. Substrate solution without enzyme was used as control. One unit (U) of enzyme activity was defined as enzyme which produce $1 \mu \mathrm{mol}$ of tyrosine per min.

Protein concentration was analyzed by Bradford's method ${ }^{11}$ using reagents consisted of $100 \mathrm{mg}$ Coomassie Brilliant Blue (CBB) G-250 in $50 \mathrm{~mL}$ ethanol $95 \%$ and $100 \mathrm{~mL}$ phosphate acid $85 \%$ in $1 \mathrm{~L}$. Bovine serum albumin was used as the protein standard. Triplicate experiments were conducted for each measurements.

Effect of $\mathrm{pH}$ and temperature on collagenase activity: Collagenase activity of the enzyme was measured using buffer universal pH 2-12 containing 0.029 M of A solution (citrate acid, phosphate acid, borate acid and dietilbarbiturate acid) and $\mathrm{B}$ solution $(\mathrm{NaOH} 0.2 \mathrm{~N})$ in the absence and presence of $10 \mathrm{mM} \mathrm{CaCl}_{2}$ at a temperature of $50{ }^{\circ} \mathrm{C}$, with collagen $(0.5 \%)$ as the substrate. Plot of enzyme relative activity against $\mathrm{pH}$ was constructed to determine the optimum $\mathrm{pH}$ for the reaction. The effect of temperature on collagenase activity in the absence and presence of $10 \mathrm{mM} \mathrm{CaCl}_{2}$ was measured at 30, 40, 50, 60, 70,80 and $90{ }^{\circ} \mathrm{C}$ at $\mathrm{pH} 7$, with collagen $(0.5 \%)$ as the substrate.

The thermal stability of enzyme was measured from the residual collagenase activities after incubation the enzyme solution at various temperature $\left(50\right.$ and $\left.70{ }^{\circ} \mathrm{C}\right)$. Sample were taken and measured their activities every $20 \mathrm{~min}$.

Effect of metal ions on collagenase activity: The effects of various metal ions were tested on the activity of enzyme at $50{ }^{\circ} \mathrm{C}$ in universal buffer $\mathrm{pH} 7$, with collagen $5 \%(\mathrm{w} / \mathrm{v})$ as the substrate. The metal ions, such as $\mathrm{CaCl}_{2}$ and $\mathrm{ZnCl}_{2}$ at the final concentration with 1,5 and $10 \mathrm{mM}$ and $\mathrm{CoCl}_{2}, \mathrm{MgCl}_{2}, \mathrm{FeCl}_{2}$ and $\mathrm{CuCl}_{2}$ at the final concentration with $1 \mathrm{mM}$ were applied in the reaction mixture. The residual activity was determined as a percentage of the activity in the control sample without added metal ions.

Determination of molecular weight: Molecular weight was estimated by electrophoresis under denaturating polyacrylamide-SDS (SDS-PAGE) with $8 \%$ polyacrylamide gels ${ }^{12}$. The standard moleculer weight markers were phosphorylase b (97 kDa), bovine serum albumin (66 kDa), ovalbumin (45 $\mathrm{kDa})$, carbonic anhydrase $(30 \mathrm{kDa})$ and lysozyme $(14.3 \mathrm{kDa})$. Enzymes activity in situ was determined by zymogram following Choi et al. ${ }^{13}$. Acrylamide gel was copolymerized with the $1 \%$ protein (collagen) substrates. Following electrophoresis, the gel was soaked in Triton X-100 2.5\% for $1 \mathrm{~h}$ and furthur incubated for enzyme substrate reaction in buffer Tris$\mathrm{Cl} 10 \mathrm{mM}, \mathrm{pH} 8,37{ }^{\circ} \mathrm{C}$ for $24 \mathrm{~h}$. The activity bands was visualized after incubation in staining solution $(50 \%$ methanol
$+10 \%$ acetic acid $+0.06 \%$ coomassie brilliant blue R-250) for 30 min followed by incubation in destaining solution $(5 \%$ methanol $+7.5 \%$ acetic acid). Positive result was seen as clear bands.

\section{Substrate specificity determination}

Collagenase activity on various protein substrates: casein $(0.5 \%)$ gelatin $(0.5 \%)$ and fibrin $(0.5 \%)$ was assayed by mixing $0.2 \mathrm{~mL}$ of enzyme and $1 \mathrm{~mL}$ of substrate (collagen, casein, gelatin and fibrin) and $1 \mathrm{~mL} 0.05 \mathrm{M}$ buffer phosphate $\mathrm{pH}$ 7. The collagenase activity was measured as described previously.

\section{RESULTS AND DISCUSSION}

Effect of collagen on enzyme production: Fig. 1 showed collagenase production of B. licheniformis 11.4 in LB media and addition of collagen into the media (modified LB media). The optimum production time of B. licheniformis F11.4 was between 20-35 h of fermentation, with specific enzyme activity of $0.157 \mathrm{U} / \mathrm{mg}$ protein. Addition of collagen into the media, resulted in different responses (Fig. 1). In this case, the concentration of tryptone and yeast extract in the original LB media was reduced by half and collagen was added at $5 \%$. The activity of Bacillus licheniformis F11.4 was increased from $0.157 \mathrm{U} / \mathrm{mg}$ protein to $0.546 \mathrm{U} / \mathrm{mg}$ protein with optimum production being $10 \mathrm{~h}$ incubation which is within the logarithmic
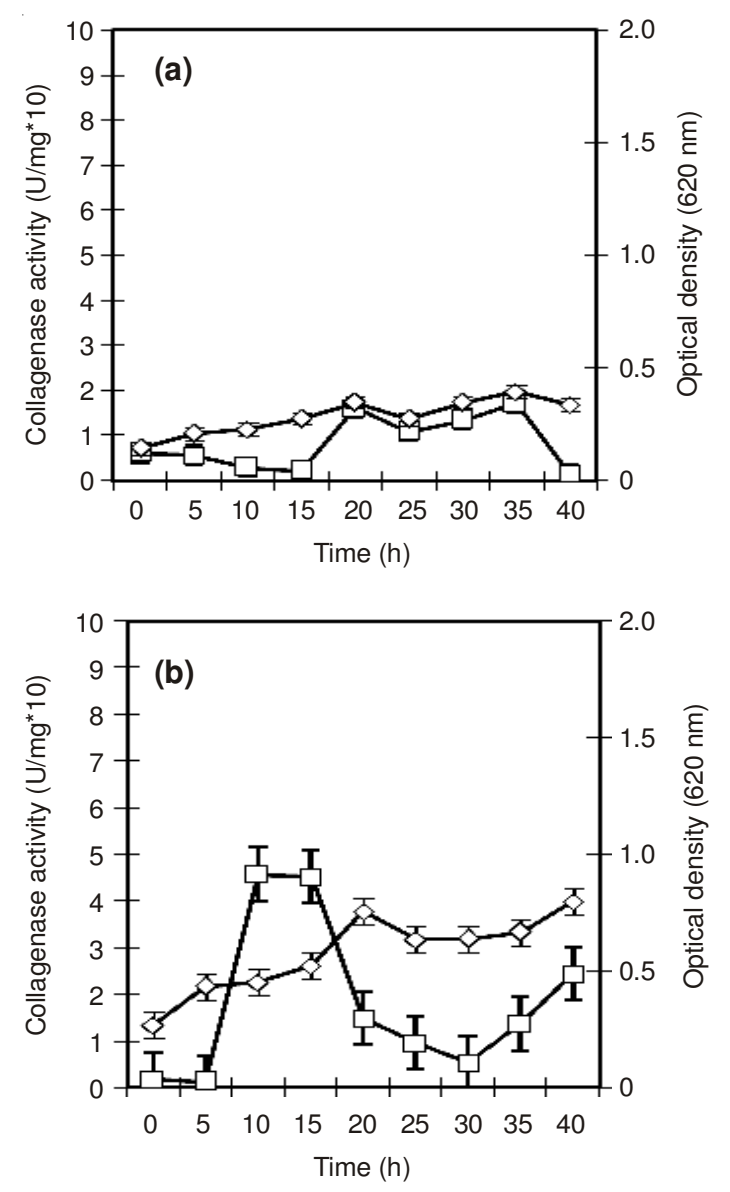

Fig. 1. Collagenase production $(\square)$ and Growth $(\diamond)$ as a function of cultivation time by Bacillus licheniformis F11.4 grown on LB media (a) and modified LB supplemented with collagen (5\%) (b) in shake flasks at initial $\mathrm{pH} 7$ and at $50{ }^{\circ} \mathrm{C}$ 
growth phase. The optimum enzyme production of $B$. licheniformis F11.4 in LB media was achieved at the stationary growth phase, while that of Bacillus licheniformis F11.4 in modified LB media was achieved during logarithmic growth phase. Induction of collagenase enzyme was clearly observed in B. licheniformis F11.4 which responded to collagen addition by increasing the collagenase enzyme activity rapidly. The high enzyme activity was short lived and rapidly reduced following its optimum activity at $10 \mathrm{~h}$ of incubation. This may relate to the possible auto degradation of the protease.

B. licheniformis F11.4 of Palembang Indonesia was found to produce extracellular alkaline collagenase enzyme. Induction of collagenase enzyme was clearly observed in $B$. licheniformis F11.4 which responded to collagen addition by increasing the collagenase enzyme activity rapidly. The high enzyme activity was short lived and rapidly reduced following its optimum activity at $10 \mathrm{~h}$ of incubation. The optimum fermentation time for synthesis of a particular enzyme is affected not only by different bacterial strain but also by varieties of fermentation conditions. In general, the Bacillus subtilis $\mathrm{CN} 2$ was reported to synthesize protease optimally by $14 \mathrm{~h}$ of fermentation time ${ }^{14}$. Shorter optimum fermentation time of protease, i.e. $9 \mathrm{~h}$ was reported when Bacillus SMIA-2 was grown in media containing tri sodium citrate $1 \%{ }^{15}$. Bacillus subtilis PE-11 produced protease optimally at longer incubation time, that is by $48 \mathrm{~h}$ when grown in nutrient broth ${ }^{16}$.

Effect of $\mathbf{p H}$ on collagenase activity: A pH range between 2 and 12 was used to study the effect of $\mathrm{pH}$ on collagenase activity (Fig. 2). Optimum $\mathrm{pH}$ was found to be 9 . At $\mathrm{pH} 5$ only $8.3 \%$ of the maximum enzyme activity was obtained, increasing to 38.6 and $91 \%$ at pH 6 and 7, respectively. The collagenase displayed a broad $\mathrm{pH}$ activity profile in the neutral to basic range, at $\mathrm{pH} 12$ the activity of enzyme was still at $80 \%$ of its optimum level.

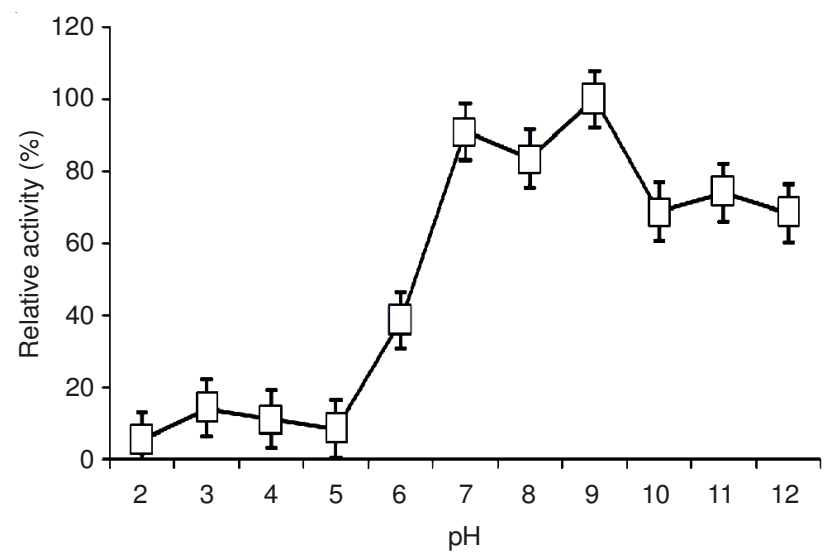

Fig. 2. Activity of collagenase of B. licheniformis F11.4 at different $\mathrm{pH}$ values. Collagenase activity was measured at $50{ }^{\circ} \mathrm{C}$ in the buffer universal. Each value represents the mean $\pm \mathrm{SE}$ of three independent experiments

The $\mathrm{pH}$ optimum of the enzyme was 9 (Fig. 2), which was also observed in collagenase from Bacillus $s p$. MO- $1^{17}$. and Streptomyces parvulus 5 . Interestingly we found that the collagenase of $B$. licheniformis F11.4 was still significantly active at $\mathrm{pH}$ 12. Consequently, this collagenase belongs to the group of alkaline protease.
Effect of temperature on collagenase activity: The collagenase activity was assayed at different temperature ranging from 30 to $90{ }^{\circ} \mathrm{C}$ at a constant $\mathrm{pH}$ of 9 , the hydrolysis of collagen was also influenced by temperature (Fig. 3). Enzyme activity increased with temperature within the range of 30 to $50{ }^{\circ} \mathrm{C}$. A reduction in enzyme activity was observed above $60^{\circ} \mathrm{C}$.

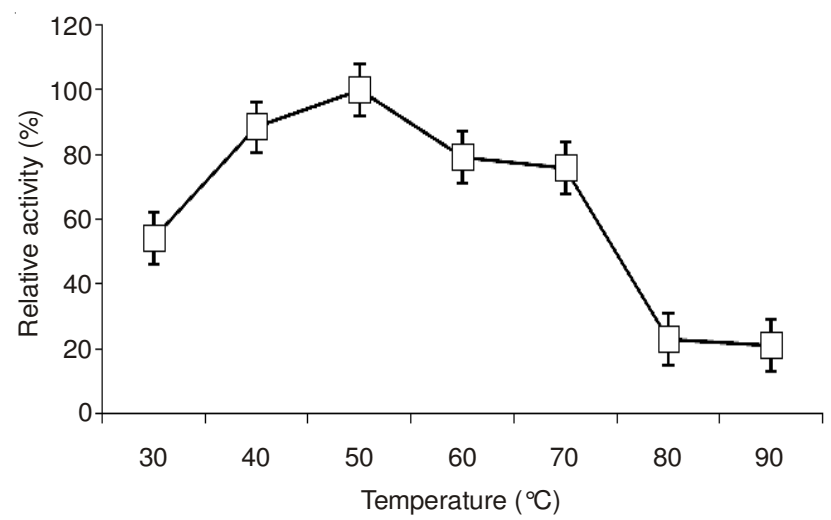

Fig. 3. Effects of temperature on collagenase activity. Collagenase activity was determined in the buffer phosphate $0.05 \mathrm{M} \mathrm{pH} 7$. Each value represents the mean $\pm \mathrm{SE}$ of three independent experiments

The $\mathrm{pH}$ optimum of the enzyme was 9, which was also observed in collagenase from Bacillus $s p$. MO- $1^{17}$ and Streptomyces parvulus ${ }^{5}$. Interestingly we found that the collagenase of B. licheniformis F11.4 was still significantly active at $\mathrm{pH}$ 12. Consequently, this collagenase belongs to the group of alkaline protease. The optimum temperature of this collagenase was $50{ }^{\circ} \mathrm{C}$ which is similar to Bacillus subtilis $\mathrm{FS}-2^{18}$.

Thermostability: Temperature stability was studied at 50 and $70{ }^{\circ} \mathrm{C}$ (Fig. 4). The residual enzyme activity of heat treatment at $50{ }^{\circ} \mathrm{C}$ was higher than at $70^{\circ} \mathrm{C}$, while their changing curve was similar. The result showed that the collagenase kept relatively stable and retained a bove $50 \%$ activity under $20 \mathrm{~min}$ incubation at 50 and $70{ }^{\circ} \mathrm{C}$. However, the enzyme activity decreased gradually after 20 min incubation.

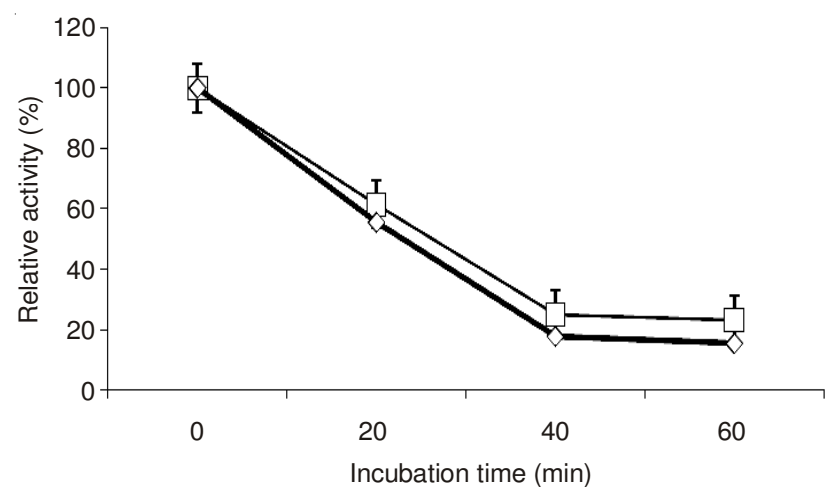

Fig. 4. Thermostability of collagenase from Bacillus licheniformis F11.4 at $50{ }^{\circ} \mathrm{C}(\square)$ and $70{ }^{\circ} \mathrm{C}(\diamond)$ Collagenase activity was determined in the buffer phosphate $0.05 \mathrm{M} \mathrm{pH} \mathrm{7.0.} \mathrm{Residual} \mathrm{activity} \mathrm{monitored}$ at various time interval after incubation at various temperature. Each value represents the mean $\pm \mathrm{SE}$ of three independent experiments

Effect of metal ions on collagenase activity: The effect of different metal ions on collagenase is shown in Table-1. A significant inhibitory effect was observed in presence of $\mathrm{Cu}^{2+}$. 


\begin{tabular}{ccc}
\hline \multicolumn{3}{c}{ TABLE-1 } \\
\multicolumn{3}{c}{ EFFECTS OF METAL IONS ON COLLAGENASE ACTIVITY } \\
\hline Metal ions & Concentration (mM) & Relative activity (\%) \\
\hline Control & - & 100 \\
$\mathrm{CaCl}_{2}$ & 1 & 112.11 \\
$\mathrm{CaCl}_{2}$ & 5 & 105.19 \\
$\mathrm{CaCl}_{2}$ & 10 & 93.28 \\
$\mathrm{ZnCl}_{2}$ & 1 & 98.31 \\
$\mathrm{ZnCl}_{2}$ & 5 & 107.93 \\
$\mathrm{ZnCl}_{2}$ & 10 & 94.40 \\
$\mathrm{CuCl}_{2}$ & 1 & 60.61 \\
$\mathrm{FeCl}_{2}$ & 1 & 71.41 \\
$\mathrm{CoCl}_{2}$ & 1 & 159.76 \\
$\mathrm{MgCl}_{2}$ & 1 & 123.75 \\
\hline
\end{tabular}

Collagenase activity was stimulated by $\mathrm{Co}^{2+}(159.8 \%), \mathrm{Mg}^{2+}$ (123.7\%) and $\mathrm{Ca}^{2+}(112.1 \%)$

Collagenase activity was inhibited by $\mathrm{Cu}^{2+}(1 \mathrm{mM})$ and stimulated by $\mathrm{Co}^{2+}(1 \mathrm{mM}), \mathrm{Mg}^{2+}(1 \mathrm{mM})$ and $\mathrm{Ca}^{2+}(1 \mathrm{mM})$. Similar effect of $\mathrm{Ca}^{2+}$ and $\mathrm{Mg}^{2+}$ on the activity of collagenase were also observed ${ }^{4,19}$. These result suggest that these metal ions apparently played a vital role in maintaining the active conformation of the enzyme ${ }^{20}$.

Apparent molecular weight of collagenase: SDS analysis of the crude extract revealed several protein bands and zymography analysis indicated that the molecular mass of the collagenase fraction were approximately 124, 35, 31 and 26 kDa (Fig. 5), which appeared as clear bands. (a)

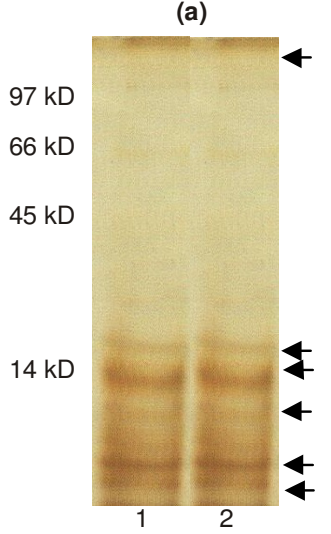

(c)

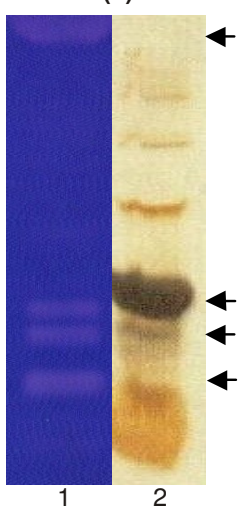

Fig. 5. SDS-PAGE (a) and Zymogram (b) of collagenase from $B$. licheniformis F11.4. Lane 1, molecular mass standards: phosphorylase b (97 kDa), bovine serum albumin $(66 \mathrm{kDa})$, ovalbumin $(45 \mathrm{kDa})$, carbonic anhydrase $(30 \mathrm{kDa})$ and lysozyme (14.3 kDa); lane 2, crude collagenase; SDS-PAGE was done under reduced conditions

Zymography analysis indicated that the apparent molecular mass of the collagenase fractions were approximately 124, 35, 31 and $26 \mathrm{kDa}$ (Fig. 5). Multiple collagenase in the range 14.5 -210 kDa produced by bacteria have been reported previously. In the case of Bacillus licheniformis N22, two collagenase corresponding to 29 and $120 \mathrm{kDa}$ were found $\mathrm{d}^{3}$.

Substrate specifity of collagenase: The activity of collagenase on various protein substrates (collagen, casein, gelatin and fibrin) is shown in Table-2. All experiment for substrate were done under the same conditions. This collagenase were highly active for casein and collagen, more than gelatin and fibrin.
TABLE-2

SUBSTRATE SPECIFICITY OF THE COLLAGENASE

\begin{tabular}{cc}
\hline Substrate & Relative activity $(\%)$ \\
\hline Collagen & 100.00 \\
Casein & 217.88 \\
Gelatin & 71.43 \\
Fibrin & 38.49 \\
\hline
\end{tabular}

The bacteria produced several collagenases, probably to hydrolyze to diverse protein substrates found in nature. The capability of diverse substrates degradation was confirmed. In this study, the enzyme was found capable of hydrolyze not only collagen but also casein, gelatin and fibrin. Even though the best substrate is still casein, the enzyme activity to collagen was higher that the other 2 substrates (gelatin and fibrin).

\section{ACKNOWLEDGEMENTS}

This research was support by Competitive Grant from Directorate General of Higher Education (DIKTI), Ministry of National Education Republic Indonesia. Bacillus licheniformis used in this research were the result of research collaboration between Indonesia (Agency for the Assessment and Application of Technology Jakarta ) and German (IndoGerman Biotechnology). The authors gratefully acknowledged for Dr. Kerstin Hoffmann and her colleague from Institut für Molekulare Mikrobiologie, Westfälische Wilhelms-Universität Münster, Germany for contruction of mutant Bacillus licheniformis F11.4

\section{REFERENCES}

1. M.D. Bond and H.E. Van Wart, Biochem., 23, 3085 (1984).

2. T. Hisano, S. Abe, M. Wakashiro, A. Kimura and K. Murata, J. Ferment. Bioeng., 68, 399 (1989).

3. S. Asdornnithee, K. Akiyama, T. Sasaki and R. Takata, J. Ferment. Bioeng., 78, 283 (1994)

4. Q. Wu, C. Li, C. Li, H. Chen and L. Shuliang, Appl. Biochem. Biotechnol., 160, 129 (2010).

5. Y. Sakurai, H. Inoue, W. Nishii, T. Takahashi, Y. Iino, M. Yamamoto and K. Takahashi, Biosci. Biotechnol. Biochem., 73, 21 (2009).

6. D. Petrova, A. Derekova and S. Vlahov, Folia Microbiol., 51, 93 (2006).

7. S. Asdornnithee, K. Akiyama, T. Sasaki and R. Takata, Biosci. Biotechnol. Biochem., 57, 1894 (1993).

8. J. Waldeck, D. Daum, B. Bisping and F. Meinhardt, Appl. Environ. Microbiol., 72, 7879 (2006).

9. K. Hoffmann, G. Daum, M. Koster, W.M. Kulicke, H. Meyer-Rammes, B. Bisping and F. Meinhardt, Appl. Environ. Microbiol., 76, 8211 (2010).

10. H.U. Bergmeyer, M. Graß1 and H.E. Walter, in ed.: H.U. Bergmeyer and M. Grapl, Methods of Enzymatic Analysis, Weinheim: Verlag Chemie (1983).

11. M.M. Bradford, Anal. Biochem., 72, 248 (1976).

12. U.K. Laemmli, Nature, 227, 680 (1970).

13. N.S. Choi, K.S. Yoon, J.Y. Lee, K.Y. Han and S.H. Kim, J. Biochem. Mol. Biol., 34, 531 (2001).

14. I.H. Tran and H. Nagano, J. Food Sci., 67, 1184 (2002).

15. W.C.A. Nascimento and M.L.L. Martins, Braz. J. Microbiol., 35, 91 (2004).

16. K. Adinarayana, P. Ellaiah and D.S. Prasad, AAPS Pharm. Sci. Tech., 4, 440 (2003).

17. M. Okamoto, Y. Yonejima, Y. Tsujimoto, Y. Suzuki and K. Watanabe, Appl. Microbiol. Biotechnol., 57, 103 (2001).

18. N. Hiroko and A.T. Kim, Biosci. Biotechnol. Biochem., 64, 181 (1999).

19. R. Chakraborty and A.L. Chandra, J. Appl. Bacteriol., 61, 331 (1986).

20. K.B. Beg, V. Sahai and R. Gupta, Process Biochem., 39, 203 (2003). 